\title{
On two rare spider species of the genus Alopecosa Simon, 1885 (Aranei: Lycosidae) from the South Urals
}

\section{О двух редких вида пауков рода Alopecosa Simon, 1885 (Aranei: Lycosidae) с Южного Урала}

\author{
S.L. Esyunin*, T.K. Tuneva** \\ С. $\Lambda$. Есюнин*, Т.К. Тунёва**
}

\footnotetext{
* Perm State University, Bukireva Str. 15, Perm 614990 Russia. E-mail: Sergei.Esyunin@psu.ru

** Institute of Plants and Animals Ecology Ural branch RAS, 202, 8 March Str., Ekaterinburg, Russia, 620144, tuneva@ipae.uran.ru

* Пермский Государственный Университет, ул. Букирева 15, Пермь 614990, Россия

** Институт экологии растений и животных УрО РАН, 620144, Екатеринбург, ул. 8 Марта, 202
}

KEY WORDS: Spider, Lycosidae, Alopecosa, the southern Transuralia.

КЛЮЧЕВЫЕ СЛОВА: Пауки, Lycosidae, Alopecosa, южное Зауралье.

ABSTRACT. A rare wolf-spider species Alopecosa azsheganovae Esyunin, 1996 is redescribed on the basis of specimens collected from the type locality: Troitskii Reserve, the southern Transuralia. New records, diagnosis and ecological data are given for Alopecosa kungurica Esyunin, 1996. The solivaga species group is defined to include not less than 11 species predominantly distributed in Asia.

РЕЗЮМЕ. Редкий вид пауков-волков Alopecosa azsheganovae Esyunin, 1996 переописывается из типового местообитания: Троицкий заказник, южное Зауралье. Для Alopecosa kungurica Esyunin, 1996 приведены новые указания, диагноз и данные по экологии. Обосновывается выделение группы solivaga рода Alopecosa. Группа содержит не менее 11 видов, распространенных преимущественно в Азии.

\section{Introduction}

Of the 21 wolf-spiders of the genus Alopecosa Simon, 1885 recorded from the Urals, two species Alopecosa azsheganovae Esyunin, 1996 and $A$. kungurica Esyunin, 1996 - are considered endemics of this region. Both are rare species known to date from a few specimens. New material received from the time of their original descriptions allows us to clarify the diagnoses and variation of both species and to extend our knowledge of their distribution and ecology.

The material examined has been deposited at the Manchester Museum, the University of Manchester, UK (curator: D.V. Logunov).

Dried uncoated copulatory organs were studied by means of SEM (Hitachi TM3000), with BSE (backscattered electrons) detector at $15 \mathrm{kV}$ accelerating voltage. All images were stored electronically as TIFF files at a resolution of 600 pixels inch ${ }^{-1}$.

The following abbreviations are used: a - apical, AME and ALE - anterior median and lateral eyes, $\mathrm{d}$ dorsal, pl - prolateral, PME and PLE - posterior median and lateral eyes $\mathrm{rl}$ - retrolateral, $\mathrm{v}$ - ventral. All measurements are in $\mathrm{mm}$.

\section{Alopecosa azsheganovae Esyunin, 1996} Figs $1 \mathrm{~A}-\mathrm{C}, 2$. 3,4 ( $(+)$

Alopecosa azsheganovae sp.n. — Esyunin, 1996: 1149, Fig. 4:

MATERIAL. 2 우, Russia, Chelyabinsk Region, Troitskii Reserve, steppe, 26.VI-10.VII.2005, A. Kuznetsova.

DESCRIPTION. Female. Total length 9.7(9.010.9). Carapace length 4.5(4.3-4.8), width 3.4(3.33.5). Chelicerae length 2.1(1.9-2.2). Clypeus 0.23. Diameter of eyes: ALE - 0.15, AME - 0.20, PLE 0.30, PME - 0.38. Posterior eyes quadrangle trapeziform: PLE-PLE - 1.38, PME-PME - 1.05, PLE-PME - 1.03 .

Coloration. Carapace dark brown, with a brown longitudinal median stripe (Fig. 1C). Chelicerae dark brown (almost black). Sternum dark brown. Pedipalps brown, with darkened tips. Legs dark brown, but patella ventrally yellow-brown and femora dorsally with light brown sports. Abdomen dorsally grey, ventrally yellow-gray.

Armament of leg femora: T1

\begin{tabular}{|l|l|l|l|}
\hline Leg & \multicolumn{1}{|c|}{ Femur } & \multicolumn{1}{|c|}{ Tibia } & \multicolumn{1}{|c|}{ Metatarsus } \\
\hline I & d 1-1-1, pl 0-0-1, & pl 0-1-1, & pl 0-1-0, \\
& rl 0-0-1 & v 2-2-2a & v 2-2-3a \\
\hline II & d 1-1-1, pl 0-1-1, & pl 0-1-1, & pl 0(1)-1-0, \\
& rl 0-0-1 & v 1-1-2a & v 2-2-3a \\
\hline III, IV & d 1-1-1, pl 0-1-1, & d 1-1-0, & pl 1-1-1a, \\
& rl 0-0-1 & pl 1-1-0, & v 2-2-3a \\
& & rl 1-1-1f, & \\
& & v 2-2-2a & \\
\hline
\end{tabular}




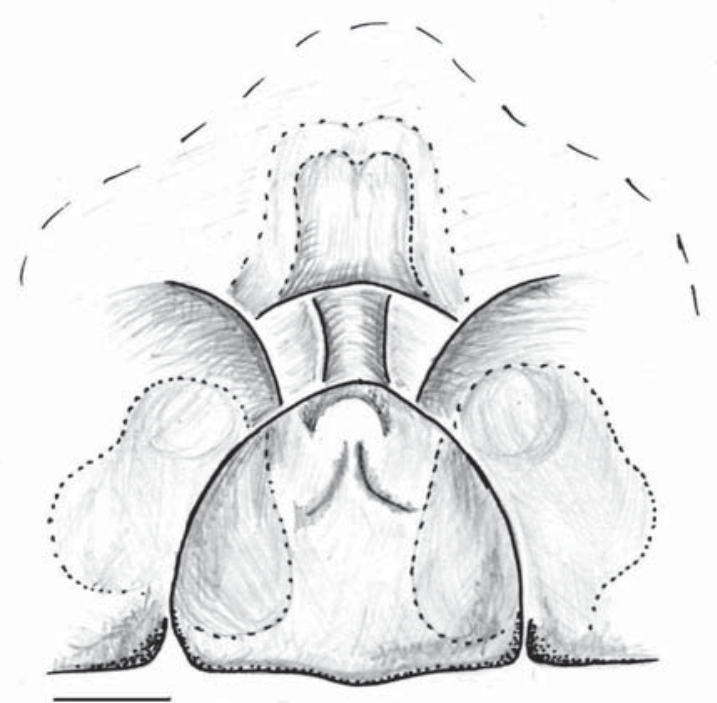

A
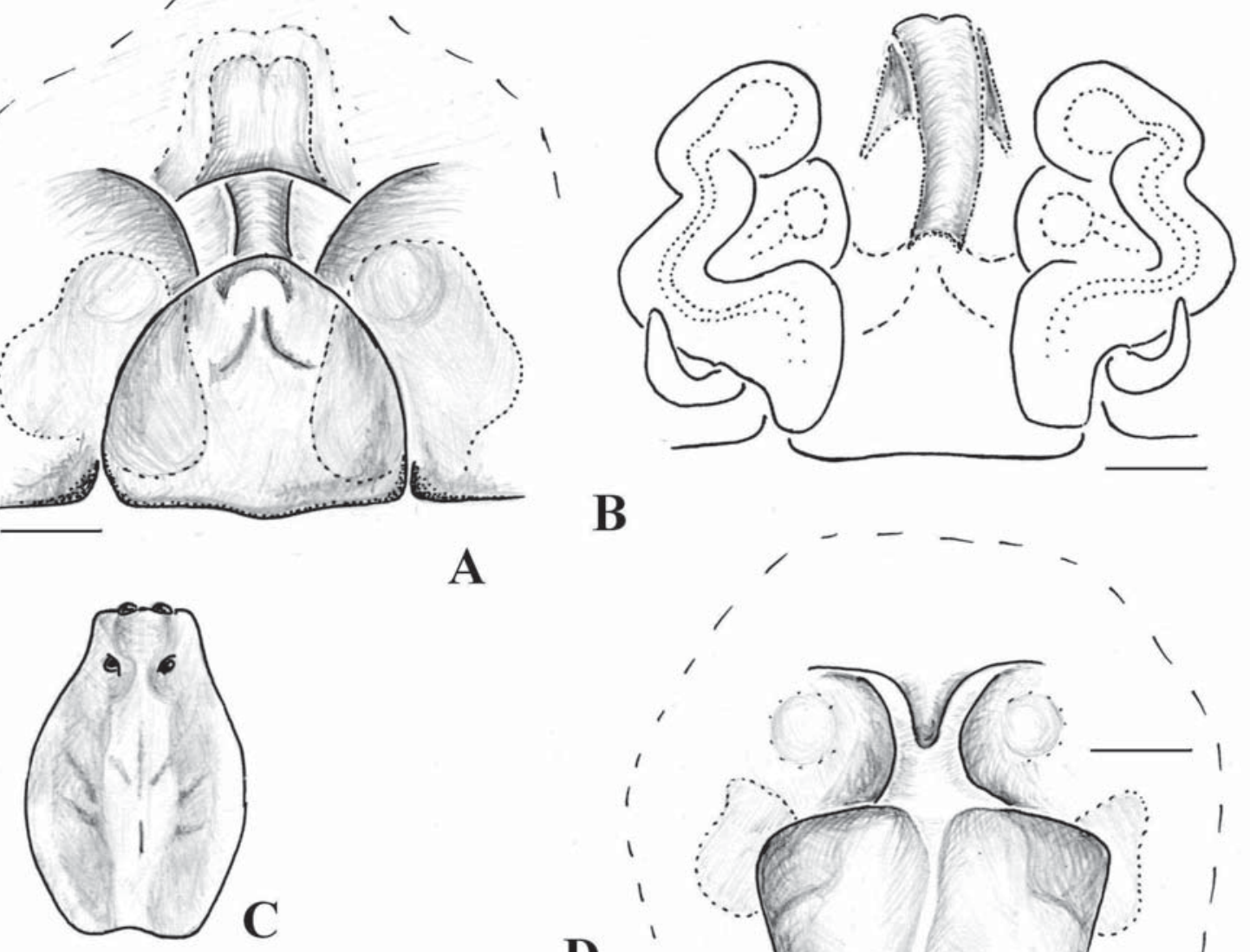

B

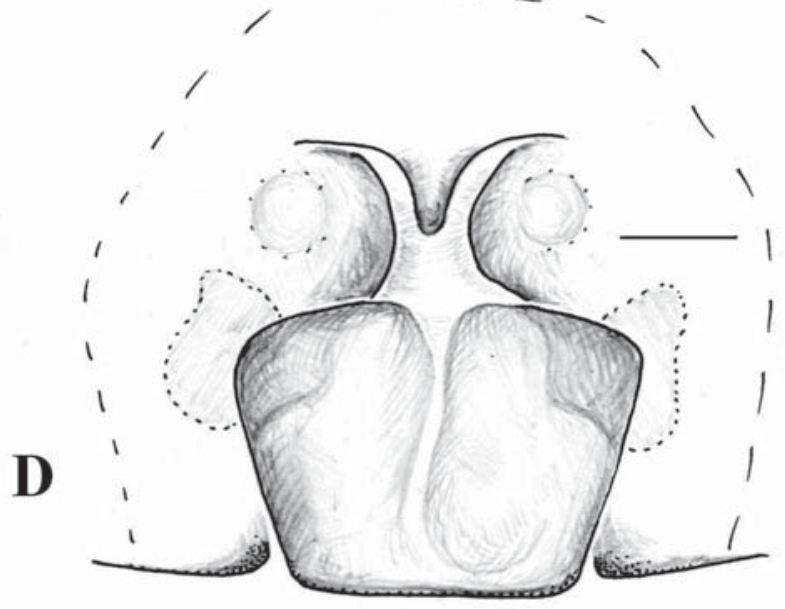

Fig. 1. Alopecosa azsheganovae Esyunin, 1996 (A-C) and Alopecosa kungurica Esyunin, 1996 (D: Chelyabinsk Area): A, D epigyne, B - spermathecae, C - carapace, scheme. Scale $0.1 \mathrm{~mm}$.

Рис. 1. Alopecosa azsheganovae Esyunin, 1996 (A-C) и Alopecosa kungurica Esyunin, 1996 (D): А, D — эпигина, В сперматека, C - карапакс, схема. Масштаб 0,1 мм.

Leg formula: IV-I-III,IV. The size of segments average (max-min): T2

\begin{tabular}{|l|c|c|c|c|c|}
\hline Leg & Femur & Patella+ Tibia & Metatarsus & Tarsus & Total \\
\hline I & 3.0 & $3.8(3.9-3.7)$ & 2.4 & 1.6 & 10.8 \\
& $(3.1-3.0)$ & & $(2.7-2.1)$ & $(1.7-1.5)$ & $(11.4-10.4)$ \\
\hline II & 2.9 & $3.7(3.8-3.6)$ & 2.4 & 1.6 & 10.6 \\
& & & $(2.5-2.1)$ & $(1.7-1.5)$ & $(10.9-10.1)$ \\
\hline III & 2.9 & 3.4 & 2.7 & 1.5 & 10.5 \\
& $(2.9-2.8)$ & & $(2.9-2.5)$ & $(1.5-1.4)$ & $(10.7-10.1)$ \\
\hline IV & 3.7 & 4.5 & 4.2 & 2.0 & 14.4 \\
& $(3.8-3.6)$ & & $(4.3-4.0)$ & $(2.0-1.9)$ & $(14.6-14.0)$ \\
\hline
\end{tabular}

Epigyne: median septum with a triangular plate (Fig. 1A, 2). Spermathecae as in Fig. $1 \mathrm{~B}$.

Male is unknown.

REMARKS. A. azsheganovae has been described from the steppe of Troitskii Reserve (east of Chelyabinsk Region, Transuralia) on the basis of three females [Esyunin, 1996]. The species was named in honour of Nina S. Azheganova who made an important contribution to the studies of Urals spiders. A type series was distributed between the three Russian museums: the Zoological Museum of the Moscow State University; the Siberian Zoological Museum of Novosibirsk; and the Zoological Museum of the Perm State University. Despite annual collecting carried out in the Troitskii Reserve, this species has not been found in almost 15 years. The two female caught in 2005, have insignificant differences from the type specimens.

A. azsheganovae seems to belong to the pulverulenta species group, as was defined by Kronestedt [1990], but clearly differs from other congeners in having the isolated triangular plate of the median septum (Fig. 1). Besides, this species is characterized by the monochrome body's colour pattern.

DISTRIBUTION: The type locality only.

ECOLOGY. Habitat: various kinds of the Stipa steppes. Phenology: +0 can be found from June to September. 


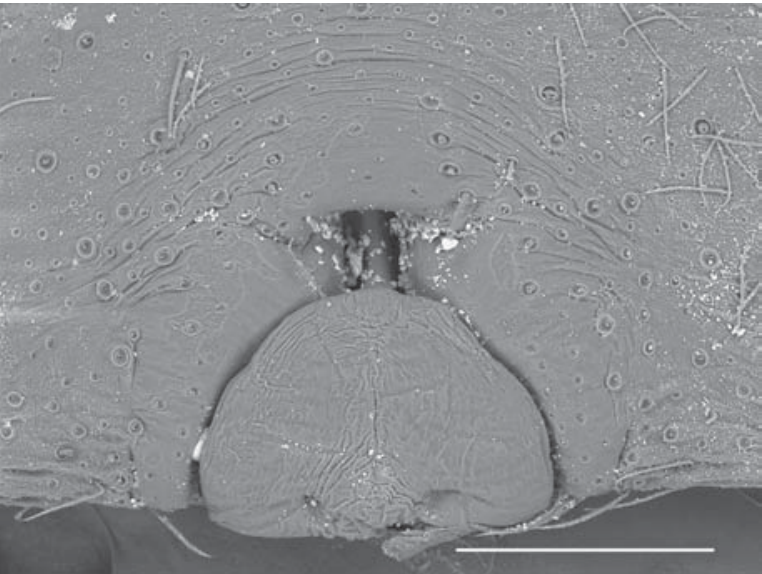

Fig. 2. Epigyne of Alopecosa azsheganovae Esyunin, 1996. Scale $300 \mu \mathrm{m}$. $300 \mu \mathrm{m}$.

\section{Alopecosa kungurica Esyunin, 1996}

Fig. 1D, 3A-D.

Alopecosa kungurica sp.n. - Esyunin, 1996: 1151, figs 1: 1$5\left(O^{7}+\right)$.

MATERIAL. Middle Urals: $1 \sigma^{7}$ (PSU-3631), Perm Area, Kishert' District, Preduralie Reserve, Mezhevoi Kamen', pitfalltraps, 20.VI.1994, S.L. Esyunin; $1 \sigma^{\prime \prime}, 12$ 우 (PSU-3343, 3631), same locality, burned-out steppe pine forest, VII.2003, 2004, S.V. Tvorogov. South Urals: 1 , Chelyabinsk Area, Ilmenskii Reserve, mountain steppe, 4.VII.1991, Pichugina.

REMARKS. The shape of epygine of A. kungurica is rather variable (see Figs $3 \mathrm{C}, \mathrm{D}$ ). The male palp with the wide tegular apophysis bearing a longitudinal crestshape outgrowth with claw-like tip (Fig. 3A). The terminal apophysis is in parallel with the embolus (Fig. 3B).

By the detailed conformation of the copulatory organs, A. kungurica differs from the generotype Alopecosa fabrilis (Clerck, 1757) - and is close to a group of Asian species related to A. solivaga (Kulc-
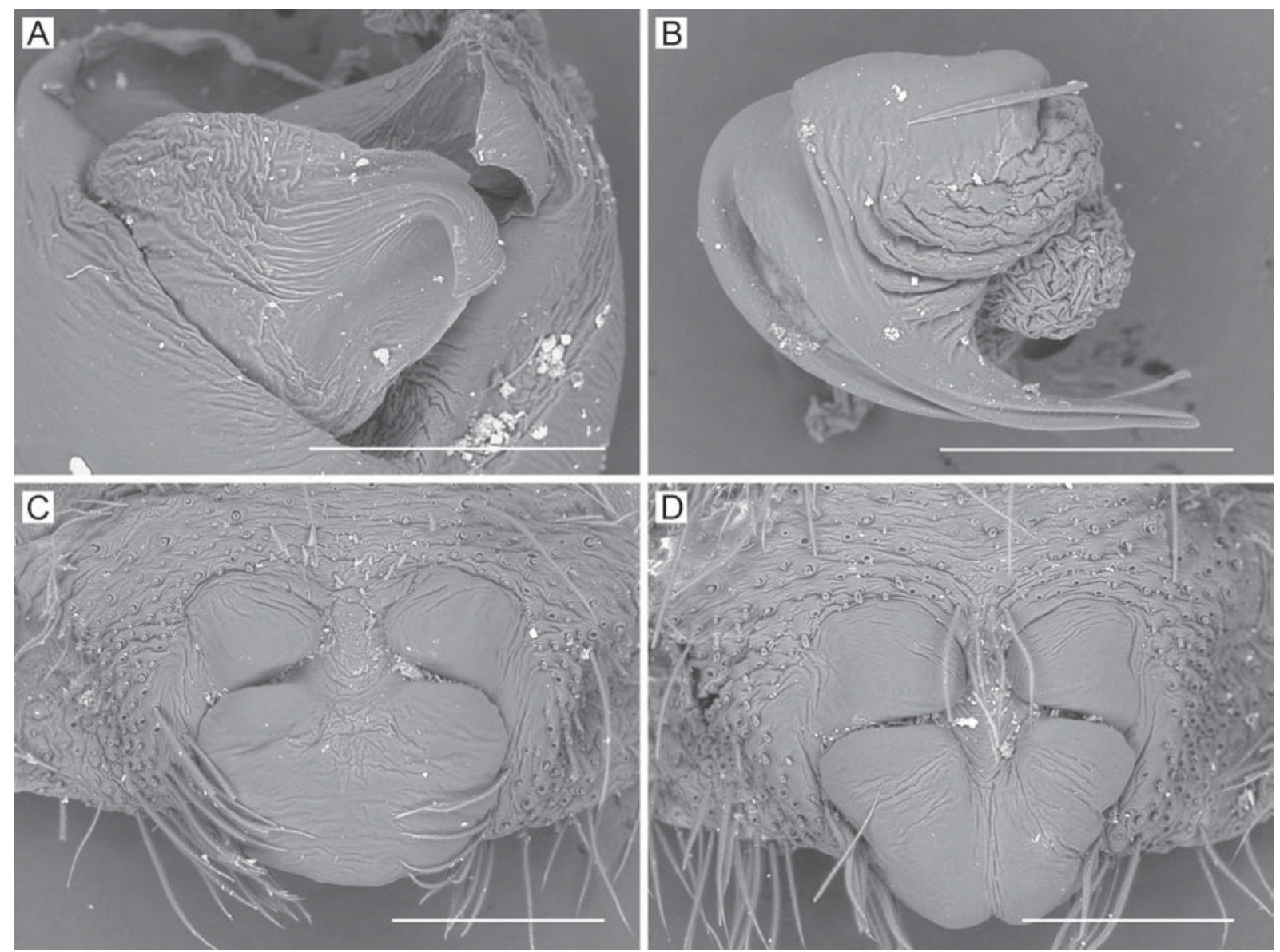

Fig. 3. Alopecosa kungurica Esyunin, 1996 (Perm Area): A - tegulum with tegular apophysis and embolic conductor, B - embolic division, C, D - epigyne. Scale $300 \mu \mathrm{m}$.

Рис. 3. Alopecosa kungurica Esyunin, 1996: А — тегулум с тегулярной апофизой и кондуктор эболюса, В — эмболюсный отдел, $\mathrm{C}, \mathrm{D}$ - эпигина. Масштаб $300 \mu \mathrm{m}$. 
zyński, 1901) which is worth considering a separate species group. Members of this group can be diagnosed by the following characters: (1) the median septum of the epigyne is plate-shaped with rounded angles, covering the epigynal atrium completely; (2) the anterior edge of epigynal atrium with two lobes; (3) the cymbium with a group of thick, basal spines; (4) the terminal apophysis large, its tip reaches the embolic tip and is in parallel with it; and (5) the median apophysis is directed laterad or laterad-backwards, its upper part having a longitudinal crest-shape outgrowth with clawlike tip. The majority of species of this group are known from their original descriptions only. The authors intend to revise all of the within the scope of Siberian fauna.

At present, solivaga species group provisionally encompasses more than 11 species: ermolaevi Saveljeva, 1972, fabifer (Schenkel, 1963), hirtipes (Kulczyński, 1907), hokkaidensis Tanaka, 1985, kungurica Esyunin, 1996, moriutii Tanaka, 1985, parahirta (Schenkel, 1963), parasibirica (Schenkel, 1963), pseudohirta (Schenkel, 1963), sibirica (Kulczyński, 1908), solivaga (Kulczyński, 1901) with 4 subspecies, and wiehle (Schenkel, 1963). It is possible that the following three species also belong to the solivaga group: A. chagyabensis $\mathrm{Hu}$ et $\mathrm{Wu}, 1987$ possessing the long bending embolus; frigens (Kulczyński, 1916) which maybe an aberrant form; and volubilis Yoo, Kim et Tanaka, 2004 having the tip of the median apophysis twirling along its axis. Species of this group are common in Asia and northern Nearctic, but are most diverse in Asia.

By the conformation of epigyne, A. kungurica (the westernmost species of the group) is most similar to $A$. ermolaevi from East Kazakhstan and A. hokkaidensis from Japan. A diagnosis of $A$. kungurica on the basis of its copulatory organs is difficult, as the species remains known from females only. Nevertheless, it can be readily distinguished from both related species by the abdominal colour pattern: black laterally and red- brown dorsally in kungurica, "dorsally grey-brown, with longitude wide yellow-white medial bland" [Saveljeva, 1972: 456] in A. ermolaevi; and "reddish brown in dorsal surface, with an indistinct lanceolate median mark and some light yellow transverse bars on posterior half; lateral and ventral surface reddish brown" [Tanaka, 1985: 68] in A. hokkaidensis.

DISTRIBUTION. The Middle and South Urals: Perm and Chelyabinsk Regions.

ECOLOGY. In the Middle Urals, A. kungurica occurs in lime stone denudations, steppe-like associations and xerophytic burnt-out places of pine forests; in the South Urals - in the mountain steppe. Phenology: $\sigma^{\top} \sigma^{\top}$ can be found from June to July; +7 from June to September.

ACKNOWLEDGEMENTS. This project was funded by the Russian Foundation for Basic Research (grants \#\# 0904-01365, 12-04-01548, 12-04-90708-моб_ст) and through a grant of the President of the Russian Federation for the support of leading scientific schools. The English of the final draft was kindly checked by D.V. Logunov, Manchester.

\section{References}

Esyunin S.L. 1996. [New wolf-spider species (Aranei, Lycosidae) from Urals] // Zool. Zhurn. Vol.75. No.8. P.1149-1159 [in Russian]

Kronestedt T. 1990. Separation of two species standing as Alpecosa aculeata (Clerck) by morphological, behavioural and ecological characters, with remarks on related species in the pulverulenta group (Araneae, Lycosidae) // Zoologica Scripta. Vol. 19. No 2. P. 203-225.

Savelyeva L.G. 1972. [New and little known species of the spider family Lycosidae (Aranei) from the East-Kazakhstan Area] // Entomol. Obozr. Vol.51. No.2. P.454-462 [in Russian].

Tanaka H. 1985. Descriptions of new species of the Lycosidae (Araneae) from Japan // Acta arachnol. Vol. 33. No.2. P.5187.

Responsible editor D.V. Logunov 